Review

\title{
The Role of Gluten in Celiac Disease and Type 1 Diabetes
}

Gloria Serena $^{1,2, \dagger}$, Stephanie Camhi ${ }^{1, \dagger}$, Craig Sturgeon ${ }^{1,2}$, Shu Yan ${ }^{1}$ and Alessio Fasano ${ }^{1, *}$

${ }^{1}$ Center for Celiac Research, Mucosal Immunology and Biology Research Center, Massachusetts General Hospital and Division of Pediatric Gastroenterology and Nutrition, Massachusetts General Hospital for Children, Boston, MA 02114, USA; E-Mails: gserena@mgh.harvard.edu (G.S.); sscamhi@partners.org (S.C.); csturgeon@mgh.harvard.edu (C.S.); syan4@mgh.harvard.edu (S.Y.)

${ }^{2}$ Graduate Program in Life Sciences, University of Maryland School of Medicine, Baltimore, MD 21201, USA

$\dagger$ These authors contributed equally to this work.

* Author to whom correspondence should be addressed; E-Mail: afasano@mgh.harvard.edu; Tel.: +1-617-724-4604.

Received: 26 June 2015 / Accepted: 11 August 2015 / Published: 26 August 2015

\begin{abstract}
Celiac disease (CD) and type 1 diabetes (T1D) are autoimmune conditions in which dietary gluten has been proven or suggested to play a pathogenic role. In CD; gluten is established as the instigator of autoimmunity; the autoimmune process is halted by removing gluten from the diet; which allows for resolution of celiac autoimmune enteropathy and subsequent normalization of serological markers of the disease. However; an analogous causative agent has not yet been identified for T1D. Nevertheless; the role of dietary gluten in development of T1D and the potentially beneficial effect of removing gluten from the diet of patients with T1D are still debated. In this review; we discuss the comorbid occurrence of CD and T1D and explore current evidences for the specific role of gluten in both conditions; specifically focusing on current evidence on the effect of gluten on the immune system and the gut microbiota.
\end{abstract}

Keywords: celiac disease; type 1 diabetes; gluten 


\section{Celiac Disease}

Celiac disease (CD) is an autoimmune enteropathy caused by the ingestion of gluten in genetically susceptible individuals. It is characterized by the presence of autoimmune antibodies, systemic clinical manifestations, small intestinal enteropathy and genetic predisposition [1]. CD is a T-cell mediated disorder where gliadin derived peptides activate immune cells in the gut lamina propria and recruit infiltrating T lymphocytes, which initiate an adaptive Th1 response and concurrent increase of interferon gamma (IFN- $\gamma$ ) and interleukin-15 (IL-15). This leads to the activation of intraepithelial lymphocyte toxicity which results in profound tissue remodeling.

The etiology of CD is influenced by both environmental and genetic factors. The most characterized genetic contribution to CD is the human leukocyte antigen system (HLA), contributing to $40 \%$ of genetic variance [2]. Major histocompatibility coplex (MHC) class II HLA DQ2 and DQ8 confer the greatest disease susceptibility. The majority of patients carry variants of DQ2 (95\%) encoded by alleles DQA1*05/DQB*02 and a minority $(5 \%)$ carries DQ8 encoded by DQA1*03/DQB1*03:02 alleles. In addition, there is evidence for gene dosage effect with increased risk for those with homozygous allotypes [3]. Genome-wide association studies and a recent dense fine mapping study report 57 non HLA loci, which account for $18 \%$ of the genetic variance [4]. Of note, HLA and other genetic susceptibility are necessary but not sufficient for disease development. Additionally, environmental causative agents for $\mathrm{CD}$, other than gliadin, have been explored.

Several studies have shown an association between active $\mathrm{CD}$ and gastrointestinal dysbiosis characterized by higher amount of Proteobacteria and Bacteroidetes and associated with a reduced abundance of the phylum Firmicutes during the acute phase of the disease [5]. A proof of concept study from our group revealed that genetically predisposed infants present a specific fecal microbiota in which Bacteroides are reduced and Firmicutes are more abundant before the onset of the disease [6]. Together, these data suggest a possible causative role of dysbiosis in the onset of CD.

Prevalence of $\mathrm{CD}$ is between $1 \%$ and $2 \%$ of the total population in North America, South America, the Middle East and North Africa, and there is preliminary evidence for similar rates in Asian populations [7]. The disease incidence is also increased in first degree family members of those with CD (10\%-15\%) and in individuals with other autoimmune diseases [8]. Of the affected population, studies suggest that only $10 \%-15 \%$ is actually diagnosed. Despite high estimates of undiagnosed cases, recent studies have also indicated a surprisingly sharp increase in the prevalence of CD over the past decades, with North America and Europe experiencing the highest increase [9].

Classical presentation of CD consists mainly of gastrointestinal symptoms associated with malabsorption including diarrhea, steatorrhea, weight loss, or failure to thrive. Other extra-intestinal symptoms include iron deficiency, recurrent abdominal pain, aphthous stomatitis, chronic fatigue, short stature and reduced bone density [10]. Serum testing is extremely reliable and forms the first line of testing for CD. Patients are first screened for serum IgA anti-tissue transglutaminse antibodies if they are not IgA deficient [11]. In individuals with IgA deficiency, serum IgG anti-tissue transglutamminase antibody levels are measured instead of traditional markers. Recently, IgG anti-deamidated gliadin has emerged as an alternative test, due to its better sensitivity and specificity (capability of discriminating false positives and false negatives) [12]. A more specific, but more expensive and operator dependent, test is sometimes used to confirm borderline results: anti endomysium $\operatorname{IgA}$. While performing the 
serologic screening, patients should remain on a gluten containing diet in order to maintain high sensitivity of test results. Finally, a confirmed diagnosis requires a small intestinal biopsy. Histological changes should show increased number of intraepithelial lymphocytes, elongated crypts and at least partial villous atrophy [10].

The definitive treatment for CD is complete elimination of the offending gluten. A gluten free diet (GFD) should cause no side effects, since gluten has limited nutritional value, but consumption of certain nutrients, in particular fibers, iron, calcium and folates tends to be lower in the GFD [12]. Strict compliance is necessary when adhering to a GFD as even small amounts of contamination can prove problematic [9]. Maximum contamination has recently been defined as $20 \mathrm{ppm}$ by both the Codex Alimentarius and Food and Drug Administration [13]. Intestinal healing and decrease of serologic markers should begin between 6 and 24 months following the initiation of GFD [12]. Currently, the only available treatment for CD patients is a strict GFD. This therapy, however, fails to induce complete improvement in $7 \%-30 \%$ of patients. Thus, the number of studies evaluating alternative therapeutic strategies for CD, such as genetically modified gluten, inhibitors of zonulin-the regulator of intestinal tight junctions_-or supplementary probiotics, have recently increased [14-17].

\section{Celiac Disease and Gluten}

Gluten is a complex molecule contained in several grains such as wheat, rye and barley $[12,18]$. The major proteic components that characterize gluten are glutenin polymers and gliadin monomers. Glutenins can be subdivided into low and high molecular weight proteins, while the gliadin protein family contains $\alpha-, \beta-, \gamma$ - and $\omega$ - types [19]. Both glutenins and gliadins are characterized by a high amount of prolines (20\%) and glutamines (40\%) that protect them from complete degradation in the gastrointestinal tract and make them difficult to digest [20].

The link between onset of CD and ingestion of gluten containing grains was established around 1950 . Since then, the role of gliadin as the environmental factor for CD has been well established [12,18]. Several studies revealed the capability of gliadin peptides to trigger an immune response in CD patients. Castellanos-Rubio and colleagues showed that intestinal biopsies from active CD patients stimulated in vitro with gliadin express a vast range of pro-inflammatory cytokines derived from a Th1/Th17 driven adaptive immune response [21]. Furthermore, Palova et al. reported that peripheral blood mononuclear cells (PBMC) from CD patients responded to gliadin by secreting interleukin 1 beta (IL-1 $\beta$ ) and interleukin-18 (IL-18) [22]. Recently, IL-15 has also been found to be up-regulated in the epithelium and the lamina propria of patients with active CD [23,24].

Presently, the chain of events by which gliadin triggers onset of clinical disease is hypothesized as the following: after oral ingestion, partially digested gliadin peptides interact with the small intestinal mucosa and trigger an innate immune response characterized by release of IL- 8 and IL- 15 from epithelial cells and lamina propria dendritic cells [25,26]. IL- 8 is a potent chemo-attractant and its production leads to the immediate recruitment of neutrophils in the lamina propria, while the release of IL-15 induces enterocyte apopotosis via $\mathrm{NKG}^{+} \mathrm{D}^{+}$cells. Specific gliadin peptides interact with CXCR3 receptors expressed on the epithetlium's apical side [27]. This interaction triggers the release of zonulin leading to increase antigen trafficking [28,29]. Gliadin peptides are then translocated into the lamina propria where they are deamidated by transglutaminase 2 [30]. Consequently to the deamidation, the peptides 
interact with macrophages and dendritic cells of the intestinal submucosa [31]. The following Th1/Th17 driven adaptive immune response is characterized by high production of pro-inflmmatory cytokines IFN- $\gamma$, tumor necrosis factor- $\alpha$ (TNF- $\alpha$ ) and interleukin-17 (IL-17), which further increase intestinal permeability and provoke damage in the intestinal mucosa [32] (Figure 1).

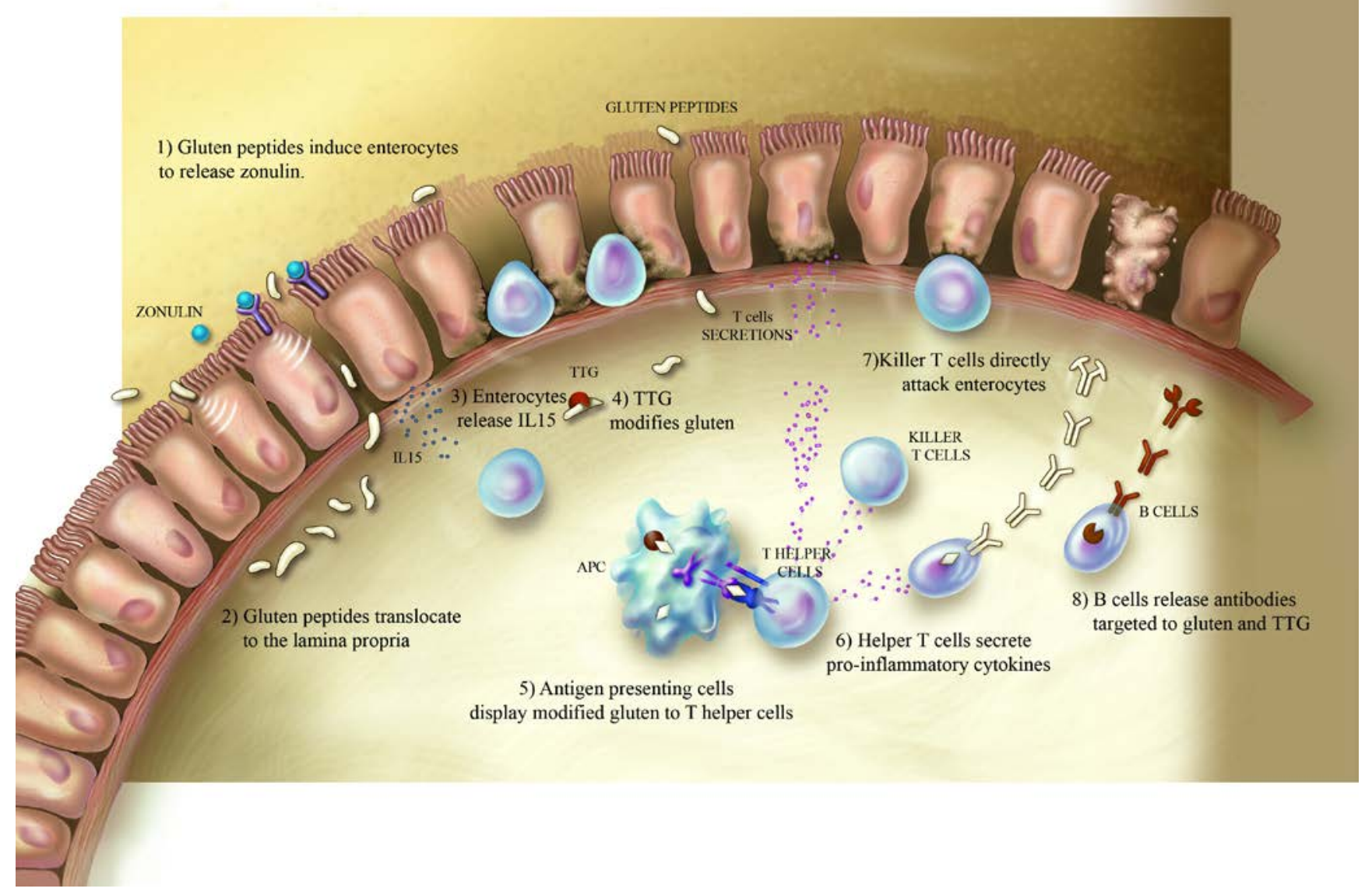

Figure 1. Mechanisms by which ingested gluten triggers celiac disease: digested gluten interacts with epithelial cells in the small intestine and triggers the disruption of tight junctions (1). The consequent increased intestinal permeability leads to the translocation of gluten peptides to the lamina propria (2) where they induce the production of IL-15 (3). In the lamina propria, gluten peptides are modified by tissue transglutaminase enzymes (4) and trigger an adaptive immune response (5-8).

Several studies have focused on the specific components of gluten that play a role in the various steps of disease onset. Many epitopes have been described and associated respectively with increased gut permeability, cytotoxic or immunomodulatory activities [33]. The majority of these epitopes are found in $\alpha$-and $\omega$-gliadins. The 57-89 peptide (33-mer) $\alpha$-gliadin fragment has been particularly well studied. It contains most of the epitopes and has been reported to have immunomodulatory effects [34]. Shan et al. identified three distinct $\mathrm{T}$ cell epitopes within its aminoacidic sequence and they demonstrated its strong proteolitic resistance during digestion. Other known peptides are the cytotoxic peptide, the gut permeating peptides and the IL-8 releasing peptide [35]. 
As with many other autoimmune diseases, $\mathrm{CD}$ has been characterized by an increased worldwide prevalence in recent decades. Rubio-Tapia et al. showed that the incidence of CD in the USA has increased five-fold in fifty years [36]; similar results have been reported in Finland, where the overall prevalence of CD increased from $1.05 \%$ to $1.99 \%$ in 20 years [37]. Catassi et al. confirmed the increase in incidence of the disease in the past three decades and demonstrated that the loss of immunological tolerance to gluten can also occur later in adulthood [9].

The reasons behind the increased prevalence of $\mathrm{CD}$ in the last 50 years are not fully understood. The rapid change in incidence suggests that this higher prevalence cannot be attributed exclusively to genetic changes in the populations, but rather to environmental factors. The hygiene hypothesis has long been considered as the most plausible explanation for the increased incidence of autoimmune diseases; however, data from developing countries suggest that this may not be the case for CD. Several studies have considered variables that may be related to the increased incidence of $\mathrm{CD}$, focusing mostly on timing of gluten introduction, amount of gluten supplemented to the diet, and the effects of breast feeding.

The introduction of gluten to Man's diet has been reported to occur around 10,000 years ago; since then, its consumption has expanded up to five-fold [38]. Many hypothesize that the increased gluten intake of the last few decades paired with the introduction of a westernized diet in many countries may play a critical role in the increased prevalence of $\mathrm{CD}$ worldwide. In the last fifty years, an increase in gluten consumption has been reported in countries like Italy and Sweden. The corresponding increase in prevalence of $\mathrm{CD}$ in the same countries suggests that the amount of gluten consumed may be considered a major risk factor for development of CD $[39,40]$. This hypothesis appears to be corroborated by studies that show the introduction of a small amount of gluten between four and six months of age reduces the risk of the disease [41]. A retrospective analysis study explored whether the increased incidence of $\mathrm{CD}$ might be due to an increased gluten content in wheat derived from wheat breeding. Domesticated modern wheat has been shown to significantly differ from wild wheat: modern wheat has larger grains and higher protein content [38]. Interestingly, the author of this study did not find clear evidence to corroborate this hypothesis. Furthermore, the lack of sufficient data regarding the incidence of CD per year made it difficult to determine if the pro capita intake of wheat or gluten might have played a role in the incidence of CD. Another important aspect speculated to be a risk factor for CD is the time of gluten introduction in the infant diet. In the mid-1980s, the Swedish epidemic of symptomatic CD coincided with the new dietary recommendation of not feeding gluten-containing foods to infants until six months of age. Interestingly, the incidence of CD decreased when an earlier introduction of gluten ( $>4$ months) was reintroduced as the standard of care in Sweden [40]. Conversely, two recent studies that followed infants deemed as high risk of $\mathrm{CD}$, due to first degree relation to a $\mathrm{CD}$ patient, concluded that the timing of gluten introduction was not a significant factor in determining disease onset, although a later introduction of gluten was shown to be associated with a delayed onset of the disease [3,42]. The same studies also considered the effects of additional biological and environmental factors such as breast feeding and genetic predisposition to CD. Particularly during the first months of life, breast-feeding is well-regarded as the optimal feeding mode for infants. The advantages of breast-feeding in the health of infants have been reported by several studies [43,44]. Human milk aids in growth and supports the child's neural and immunological development. However, the question whether breast-feeding can 
protect against the development of $\mathrm{CD}$ has been a matter of discussion for long time. An analysis of the Swedish CD epidemic reported that the development of CD in children under two years of age was reduced if they were still breast-fed when dietary gluten was introduced and that this "protective effect" of breast-feeding was even more pronounced if the infants were breast-fed also after the introduction of gluten [45]. Lionetti et al. showed that breast feeding did not modify the risk of CD among at risk-infants [3]. Similar data were confirmed by another study in which the authors concluded that CD development is not influenced by the duration of breast-feeding or by continuing breast-feeding after introduction of gluten [46].

Several studies have focused on relating intestinal dysbiosis to various diseases, among which CD is included. It has been shown that the dysbiosis characterizing active CD patients is partially reversible and linked to the presence of gluten in the diet. Nadal et al. found that the initiation of a GFD normalized the increase of gram-negative bacteria, Bacteroides and E. coli groups that characterized children with active CD [47]. Similarly, a study from Collado et al. reported that the elimination of gluten from the diet of pediatric patients led to a reduction in E. coli and Staphylococcus, which were found to be in higher abundance during the active state of the disease [5]. The beneficial effects of a GFD on the microflora and its metabolic function seem to be related to diet duration [48].

\section{Type-1 Diabetes}

T1D is an autoimmune disorder caused by the destruction of the insulin producing $\beta$-cells of the pancreas [49]. Although it is widely accepted that adults can also develop T1D, the highest incidence rate is found in adolescents [50-52]. Epidemiological studies have estimated the worldwide prevalence of T1D to be less than $1 \%$. Recent evidences, however, suggest that its incidence has been increasing $3 \%$ per year [53]. Some large scale studies, such as The Environmental Determinants of Diabetes in the Young (TEDDY) [54], The Diabetes AutoImmunity Study in the Young (DAISY) [55], and TrialNet [56], have been initiated to identify potential environmental triggers and biomarkers for T1D so that, in the future, intervention may be possible to delay or even prevent the development of this condition.

The disease's first manifestations develop when lack of insulin prevents cells from adequate glucose uptake, which is necessary and vital to cell function. Classic symptoms include polyuria, polydipsia, weight loss, fatigue, and hyperglycemia, which, if left untreated, can lead to a coma and ultimately to death [57]. Diagnosis of diabetes includes fasting blood glucose higher than $126 \mathrm{mg} / \mathrm{dL}$, any blood glucose of $200 \mathrm{mg} / \mathrm{dL}$ or an abnormal oral glucose-tolerance test [58]. Since 2009, the American Diabetes Association has modified the guidelines for diabetes diagnosis to include the measurement of glycated hemoglobin levels (A1C). This reflects the amount of blood glucose attached to hemoglobin and it is considered positive if higher than $6.5 \%$ on two occasions.

An important serological component that characterizes T1D and distinguishes it from type 2 diabetes is the presence of auto-antibodies against $\beta$-cell auto-antigens. Islet cell antibodies (ICA) were the first auto-antibodies described to be associated with the development of T1D [59]. In addition to ICA, more than $90 \%$ of T1D patients have auto-antibodies to insulin (IAA) [60], glutamic acid decarboxylase (GADA) [61], and protein tyrosine phosphatase like protein (IA2). These auto-antibodies are also used to identify subjects at high risk of developing the disease, since they are present months to years before 
symptom onset and can be detected in serum as early as six months of age in genetically susceptible individuals [62].

The exact pathogenesis of T1D is not completely understood, however it is well accepted that both genetic and environmental factors play a role. The genetic locus with the highest association to T1D is the HLA locus, which accounts for about $50 \%$ of the genetic load [63]. HLA DQ2 and DQ8 loci are the strongest determinants of diabetes susceptibility and HLA DR4 and DR3 have been shown to be associated with T1D. The heterozygous DR3/DR4 genotype is associated with the highest risk of disease onset, followed by DR3/DR3 and DR4/DR4 homozygosity [64].

Other genes that have also been associated with T1D are IL-2 receptor $\alpha$ [65], cytotoxic T lymphocyte antigen (CTLA4) [66], protein tyrosine phosphatase non-receptor 22 (PTPN22) [67], intercellular adhesion molecule 1 (ICAM1) [68], and the insulin gene (INS) [69]. In addition to genetic components, it is suggested that environmental factors may play a key role in T1D onset. The incidence of diabetes is increasing faster than can be explained by genetics alone, which is likely due to environmental changes.

Although many possible contributing environmental factors have been identified, to date none have been confirmed as a clear causative agent of T1D. The most frequently proposed candidates are viruses, such as enteroviruses [70-73], rotavirus [74,75], and rubella [52]. The potential role of these pathogens in the onset of T1D would corroborate the hygiene hypothesis [76]. In the last decades, changes in microbiome composition has also been suggested to be involved in the development of T1D by either altering intestinal permeability or modifying immune system regulation [77]. Studies in non-obese diabetic (NOD) mice in specific pathogen-free or germ free conditions confirmed the role of the microbiome in the regulation of islet specific autoimmunity [78]. Human studies have shown a correlation between T1D onset and a lower diversity and stability of the intestinal microflora, including a decreased ratio between Firmicutes and Bacteroidetes $[79,80]$. Other environmental factors such as climate and nutrition have been shown to be risk factors for T1D, but also in these cases there is no strong evidence that these agents are causative of T1D [81].

\section{Type 1 Diabetes and Gluten}

Although numerous studies have suggested a potentially pathogenic role of gluten in T1D, the exact mechanisms by which it may play a role in the onset and development of T1D are not yet fully understood (Box 1).

Studies in human samples have reported that upon stimulation with wheat proteins or their components, patients with T1D showed a heightened proliferative $\mathrm{T}$ cell response as compared to control patients [82-84]. PBMC from these patients produced significantly more pro-inflammatory cytokines compared to control subjects. Similarly, Klemetti et al. found that PBMC from T1D patients proliferated more as compared to controls when stimulated with wheat proteins [85]. This proliferative behavior, however, appeared to depend on the duration of disease. While $24 \%$ of patients with newly diagnosed T1D responded to the stimulus, only $15 \%$ of patients with longer duration of T1D and 5\% of non-disease control subjects showed proliferative behavior. Such observed alterations characterizing the adaptive immune response are not restricted to the periphery. Jejunal biopsies from patients with T1D have increased CD25 $5^{+}$mononuclear cell density as compared to control patients when stimulated with gliadin [83]. Furthermore, observations in vivo showed that rectal administration of gluten in 
T1D patients induced infiltration of CD3 and $\mathrm{T} \gamma \delta$ rectal lymphocytes in a subgroup of patients [84]. Dietary gluten has also been shown to affect components of the innate immune system, such as dendritic cells [86].

The use of animal models, such as the NOD mice or BBdp rats, have allowed for a better understanding of the effect of dietary gluten on T1D progression, even as early as during gestation. The cumulative incidence of T1D has been shown to be reduced in offspring of NOD mice fed a GFD during pregnancy [87]. Similarly, it has been found that diabetes onset is delayed in offspring of NOD mice fed a modified diet (in which wheat barley proteins were absent) during gestation [88]. These results do not seem to translate to humans, as Lamb et al. found the maternal frequency of ingestion of gluten-containing foods during the final trimester of pregnancy to have no effect on the development of T1D in offspring [89].

A reduced incidence of diabetes was observed in NOD mouse offspring from mothers fed a basal (gluten-containing) diet during gestation but a wheat barley protein-free (WBP) diet at or after weaning [88]. Similarly, offspring from basal fed mothers who started a WBP free diet after weaning had reduced T1D incidence compared to offspring with identical gestational feeding practices but who received a basal diet after weaning. Taken together, these findings suggest that the infant diet during weaning is a stronger modulator of T1D development than maternal feeding practices during gestation. In humans, the effect of timing of gluten introduction on T1D and/or IA development remains controversial. Some studies report a marked increase in risk of IA development and/or T1D incidence in infants introduced to gluten prior to three months of age or later than six months of age [90-93], while others report no effect whatsoever [94,95]. Interestingly, a Swedish group has reported that the introduction of gluten after six months of age increased risk of GADA or IA-2A positivity almost six-fold in children who also were introduced to cow's milk formula before two months of age [93]. This finding therefore suggests a synergistic effect of early exposure to cow's milk formula and late exposure to gluten.

There is strong evidence that removal of gluten from the diet can selectively be protective against development of diabetes [96,97]. Incidence of hypoglycemia is higher in NOD mice maintained on a gluten-containing diet, while a GFD casein-based diet serves to reduce incidence of hypoglycemia, delay onset of T1D, and reduce IA titers [98]. Additionally, incidence of diabetes in NOD mice maintained on a WBP-free diet is reduced as compared to mice maintained on a standard gluten containing diet ( $51 \%$ versus $81 \%$ ), and IA titers are lower in NOD mice maintained on a lifelong WBP diet or a WBP diet following weaning [88]. Hypothesized mechanisms for these advantageous effects of GFD include modification of intestinal permeability and the composition of the gut microbiota. Watts et al. found an increase in intraluminal zonulin in BBdp rats just prior to hypoglycemia, which correlated with increased intestinal permeability in the animals [99].

The elimination of gluten from the diet has been shown to be advantageous also by modulating the microbiota composition. Marietta and colleagues observed that NOD mice fed a standard gluten-containing diet had increased Barnesiella, Bifidobacterium, Tannerella and Turcibacter microbes, as compared to an increase in Akkermansia and Bacteroides microbes in GFD NOD mice [96]. In addition, NOD mice fed a GFD were observed to have greater total microbial richness than NOD mice fed a gluten-containing diet. Hansen and colleagues also reported distinct microbial signatures associated 
with diet and found a marked increase in the bacterial phylum Verrucomicrobia, TM7 and Proteobacteria in GFD NOD mice [87]. In BBdp animal models, total islet number was increased in rats housed in germ-free versus specific pathogen-free (SPF) conditions [98]. In these SPF conditions, beta cell mass was lowest in BBdp animals fed a gluten-containing diet. Taken together, these findings suggest that microbes play an important role in modulating islet and beta cell integrity, which in turn modulates development of T1D.

Box 1. Main findings about the correlation between gluten and the onset of T1D.

- In vitro studies:

- Upon stimulation with wheat proteins T cells from T1D patients show a higher proliferative and pro-inflammatory response than T cells from control subjects [85].

- Upon stimulation with gliadin, jejunal biopsies from T1D patients show increased CD25+ cell density as compared to control patients [83].

- In vivo studies:

- Incidence of T1D is reduced in offspring of NOD mice fed a GFD during pregnancy [87].

- Removal of gluten from the diet selectively protects NOD mice from developing T1D [96].

- FGD casein-based diet reduces incidence of hypoglycemia, delays onset of T1D and reduces IA titers in NOD mice [98].

- Gluten containing diet alters the composition of the innate immune system in BALB/c and NOD mice and it is correlated with an increased expression of dendritic cells activation markers in NOD mice [86].

- Human studies:

- Introduction of gluten in the diet of infants prior to 3 months of age or later than 6 months is correlated with an increase in risk of IA development and T1D incidence [91,92].

- Introduction of gluten after 6 months of age increases risk of GADA and IA-2A positivity [93].

Box 1 summarizes the main findings about the correlation between gluten and the onset of T1D.

\section{Comorbidity between Celiac Disease and Type-1 Diabetes}

The association between CD and T1D was first reported in the late 1960s. The prevalence of CD in patients with T1D is estimated to fall between 1.4\% and 19.7\% [100-103]. This comorbidity can largely be attributed to overlapping genetic HLA risk loci; in both conditions, the HLA-DQ2 and DQ8 genes have been shown to be important determinants of disease susceptibility. Additionally, some non-HLA genes such as PTPN22 and CTLA4 have been associated with either CD or T1D [67].

Usually, T1D develops prior to diagnosis of $C D$, though cases exist in which $C D$ develops as the primary disease and T1D develops later in life [104-107]. In the latter case, individuals are significantly older at T1D onset than those who develop it prior to CD. Additionally, individuals who develop CD and T1D tend to be younger at diabetes onset than those with T1D who never go on to develop CD [108].

Because of the high rate of comorbidity between CD and T1D, there is great need for a more efficient, targeted diagnostic approach. Numerous findings suggest that many CD cases in T1D patients would be 
overlooked by use of a single serological screening at T1D onset. Tsouka and colleagues recently found that $12.2 \%$ of patients who eventually came to have dual diagnosis of CD and T1D first presented with at least one negative celiac screen (in serum) after T1D diagnosis [101]. On average, 47.8 months lapsed between the first negative serological test and a positive result suggesting CD autoimmunity (CDA). Additionally, a cohort by Bakker and colleagues found that $42 \%$ of T1D patients who came to develop $\mathrm{CD}$ were not diagnosed (with CD) until 10 years following T1D onset [106]. It is also important to recognize that serological markers of CD in patients with T1D may not always prove specific or reliable. It has been recently reported that a small subset of T1D children found to have CDA will spontaneously normalize their celiac serology with a median time of 1.3 years and thus will not be diagnosed with overt CD [102,109]. Though the authors did not classify their participants in this way, those found to have transiently elevated or fluctuating levels of anti-tTG IgA are generally termed as having potential CD. In the work of Castellaneta and colleagues, a small group of T1D patients with potential CD were found to have only an infiltrative lesion or entirely normal mucosa upon inspection with upper endoscopy.

The importance of a systematically correct and timely diagnosis is highlighted by the fact that additional autoimmune diseases are often reported to occur secondary to onset of comorbid T1D and CD with autoimmune thyroid disease (ATD) presenting most commonly [105,106]. Furthermore, Shah et al. found that children with dual diagnosis are three times more likely to be vitamin D deficient as compared to healthy children without autoimmune conditions [110]. In the cohort, risk of vitamin D deficiency for children with T1D alone was increased over healthy children by only 1.5 times. This raises the question of whether bone health is affected for children diagnosed with both T1D and CD. Joshi and colleagues reported that children with T1D found to have CDA have lower bone mineral density at the whole body and lumbar spine compared to children with T1D alone. In terms of other medical complications that may arise due to dual diagnosis of CD and T1D, findings are mixed regarding whether individuals with dual diagnosis are at greater risk of retinopathy or nephropathy compared to those with T1D alone (Table 1) [111].

It has been suggested that symptoms associated with CD are more difficult to control in patients that have also T1D. Mackinder et al. showed that levels of tTG (IgA) took longer to normalize for children with dual diagnosis compared to children diagnosed with CD alone [100]. Another group found the majority of T1D children diagnosed with concomitant CD presented with gastrointestinal symptoms, all of which resolved with adoption of the gluten free diet. In addition to this, BMI and weight SDS improved significantly in these children, and a trend was observed towards an increase in insulin requirement only for children who were compliant with the gluten free diet [107]. However, it remains to be elucidated whether metabolic control improves for T1D patients with underlying concomitant CD after adoption of the GFD. Two different studies reported higher HbA1c levels and more frequent hypoglycemic episodes in T1D children found to have CDA as compared to children with T1D alone [107,111]. Conversely, others have reported no difference in insulin requirement or growth status between dual diagnosis individuals and individuals with T1D alone [106].

A growing body of evidence suggests that the beneficial effects of a GFD (for patients with concomitant $\mathrm{CD}$ ) may actually protect against development of further T1D-related complications. Compared to T1D patients without CD, Bakker and colleagues found a lower prevalence of retinopathy and lower total cholesterol in adult T1D patients with concomitant CD. Warncke et al., similarly, reported 
lower absolute systolic blood pressure in T1D patients with CD as compared to those without CD, suggesting that this modulatory effect is attributed to the GFD [108]. In the same cohort, patients with dual diagnosis had significantly lower levels of HDL cholesterol as compared to individuals with T1D alone; after institution of a GFD, these levels increased significantly and the difference between groups disappeared. It is possible that these improvements in cholesterol level could be due to the normalization of the intestinal mucosa with adoption of a GFD, demonstrating a beneficial effect of adhering to the diet.

Table 1. Main features of celiac disease and type 1 diabetes.

\begin{tabular}{|c|c|c|}
\hline Feature & Celiac Disease & Type 1 Diabetes \\
\hline Wordwide incidence & $0.6 \% *-1 \%$ & $<1 \%$ \\
\hline Contribution of HLA genes & $\begin{array}{l}\text { HLA DQ2 (DQA1*05-DQB1*02) HLA } \\
\text { DQ8 (DQA1*03-DQB1*03:02) }\end{array}$ & $\begin{array}{l}\text { HLADQ2 and/or DQ8 } \\
\text { (DRB1*0401-DQB1*03:02 and } \\
\text { DRB1*0301-DQB1*0201) }\end{array}$ \\
\hline Non-HLA candidate genes & CTLA4, PTPN22,CD28, ICOS, MYO9B & CTLA4, PTPN22, MIC-A \\
\hline Symptoms & $\begin{array}{l}\text { Diarrhea, steatorrhea, weight loss, failure } \\
\text { to thrive, iron deficiency, abdominal } \\
\text { pain, reduced bone density, chronic } \\
\text { fatigue, growth failure. }\end{array}$ & $\begin{array}{l}\text { Polyuria, polydipsia, extensive } \\
\text { hunger, weight loss, chronic fatigue, } \\
\text { reduced bone density, growth failure, } \\
\text { hyperglycemia. }\end{array}$ \\
\hline Diagnosis & $\begin{array}{l}\text { Small intestinal biopsy, generally with } \\
\text { supporting serological testing.Serologic } \\
\text { tests: IgA anti-tTG, IgG anti-tTG, IgA } \\
\text { anti-EMA, IgG DGP. }\end{array}$ & $\begin{array}{l}\text { Blood test: Fasting blood glucose } \\
\text { level, oral glucose tolerance test, A1C. } \\
\text { Serologic tests: ICA, IAA, GADA, } \\
\text { IA2 antibodies }\end{array}$ \\
\hline Comorbidities & $\begin{array}{l}\text { Type } 1 \text { diabetes, Down syndrome, Turner } \\
\text { syndrome, William's syndrome, vitiligo, } \\
\text { Addison's disease, hyperparathyroidism, } \\
\text { neuropathy, IgA nephropathy, psoriasis. }\end{array}$ & $\begin{array}{l}\text { Celiac disease, Grave's disease, } \\
\text { Hashimoto's disease, Addison } \\
\text { disease, vitiligo, autoimmune thyroid } \\
\text { disease. }\end{array}$ \\
\hline Pathogenesis & $\begin{array}{l}\text { Enteropathy is due to dysregulation of } \\
\text { the innate and adaptive immune system. } \\
\text { Alteration of intestinal permeability. }\end{array}$ & $\begin{array}{l}\text { Autoimmune destruction of pancreatic } \\
\text { insulin-producing } \beta \text {-cells by an } \\
\text { adaptive and innate immune response. } \\
\text { Alteration of intestinal permeability. }\end{array}$ \\
\hline
\end{tabular}

\section{Conclusions}

In this review, we focused on the role of gluten as an important player in the pathogenesis of CD and T1D. The high rate of comorbidity between these two autoimmune diseases and their rapidly increasing prevalence in the last few decades underscore the importance of screening in high risk patients and the need to further explore and detail the contributory role of environmental factors that may be involved.

\section{Conflicts of Interest}

The authors declare no conflict of interest. 


\section{References}

1. Castillo, N.E.; Theethira, T.G.; Leffler, D.A. The present and the future in the diagnosis and management of celiac disease. Gastroenterol. Rep. 2015, 3, 3-11. [CrossRef] [PubMed]

2. Lundin, K.E.; Sollid, L.M. Advances in coeliac disease. Curr. Opin. Gastroenterol. 2014, 30, 154-162. [CrossRef] [PubMed]

3. Lionetti, E.; Castellaneta, S.; Francavilla, R.; Pulvirenti, A.; Tonutti, E.; Amarri, S.; Barbato, M.; Barbera, C.; Barera, G.; Bellantoni, A.; et al. Introduction of gluten, HLA status, and the risk of celiac disease in children. N. Engl. J. Med. 2014, 371, 1295-1303. [CrossRef] [PubMed]

4. Gutierrez-Achury, J.; Zhernakova, A.; Pulit, S.L.; Trynka, G.; Hunt, K.A.; Romanos, J.; Raychaudhuri, S.; van Heel, D.A.; Wijmenga, C.; de Bakker, P.I. Fine mapping in the MHC region accounts for $18 \%$ additional genetic risk for celiac disease. Nat. Genet. 2015, 47, 577-578. [CrossRef] [PubMed]

5. Collado, M.C.; Donat, E.; Ribes-Koninckx, C.; Calabuig, M.; Sanz, Y. Specific duodenal and faecal bacterial groups associated with paediatric coeliac disease. J. Clin. Pathol. 2009, 62, 264-269. [CrossRef] [PubMed]

6. Sellitto, M.; Bai, G.; Serena, G.; Fricke, W.F.; Sturgeon, C.; Gajer, P.; White, J.R.; Koenig, S.S.; Sakamoto, J.; Boothe, D.; et al. Proof of concept of microbiome-metabolome analysis and delayed gluten exposure on celiac disease autoimmunity in genetically at-risk infants. PLOS ONE 2012, 7, e33387. [CrossRef] [PubMed]

7. Yap, T.W.; Chan, W.K.; Leow, A.H.; Azmi, A.N.; Loke, M.F.; Vadivelu, J.; Goh, K.L. Prevalence of serum celiac antibodies in a multiracial Asian population-A first study in the young Asian adult population of Malaysia. PLoS ONE 2015, 10, e0121908. [CrossRef] [PubMed]

8. Emilsson, L.; Wijmenga, C.; Murray, J.A.; Ludvigsson, J.F. Autoimmune Disease in First-Degree Relatives and Spouses of Individuals With Celiac Disease. Clin. Gastroenterol. Hepatol. Off. Clin. Pract. J. Am. Gastroenterol. Assoc. 2015, 13, 1271-1277. [CrossRef] [PubMed]

9. Catassi, C.; Kryszak, D.; Bhatti, B.; Sturgeon, C.; Helzlsouer, K.; Clipp, S.L.; Gelfond, D.; Puppa, E.; Sferruzza, A.; Fasano, A. Natural history of celiac disease autoimmunity in a USA cohort followed since 1974. Ann. Med. 2010, 42, 530-538. [CrossRef] [PubMed]

10. Kelly, C.P.; Bai, J.C.; Liu, E.; Leffler, D.A. Advances in diagnosis and management of celiac disease. Gastroenterology 2015, 148, 1175-1186. [CrossRef] [PubMed]

11. Dieterich, W.; Ehnis, T.; Bauer, M.; Donner, P.; Volta, U.; Riecken, E.O.; Schuppan, D. Identification of tissue transglutaminase as the autoantigen of celiac disease. Nat. Med. 1997, 3, 797-801. [CrossRef] [PubMed]

12. Fasano, A.; Catassi, C. Clinical practice: Celiac disease. N. Engl. J. Med. 2012, 367, 2419-2426. [CrossRef] [PubMed]

13. Lee, H.J.; Andreson, Z.; Ryu, D. Gluten free contamination in foods labeles "Gluten free" in United States. J. Food Prot. 2014, 77, 1830-1833. [CrossRef] [PubMed]

14. Fasano, A.; Not, T.; Wang, W.; Uzzau, S.; Berti, I.; Tommasini, A.; Goldblum, S.E. Zonulin, a newly discovered modulator of intestinal permeability, and its expression in coeliac disease. Lancet 2000, 355, 1518-1519. [CrossRef] 
15. Fasano, A. Surprises from celiac disease. Sci. Am. 2009, 301, 54-61. [CrossRef] [PubMed]

16. Maiuri, L.; Ciacci, C.; Ricciardelli, I.; Vacca, L.; Raia, V.; Rispo, A.; Griffin, M.; Issekutz, T.; Quaratino, S.; Londei, M. Unexpected role of surface transglutaminase type II in celiac disease. Gastroenterology 2005, 129, 1400-1413. [CrossRef] [PubMed]

17. Gianfrani, C.; Siciliano, R.A.; Facchiano, A.M.; Camarca, A.; Mazzeo, M.F.; Costantini, S.; Salvati, V.M.; Maurano, F.; Mazzarella, G.; Iaquinto, G.; et al. Transamidation of wheat flour inhibits the response to gliadin of intestinal T cells in celiac disease. Gastroenterology 2007, 133, 780-789. [CrossRef] [PubMed]

18. Meresse, B.; Ripoche, J.; Heyman, M.; Cerf-Bensussan, N. Celiac disease: From oral tolerance to intestinal inflammation, autoimmunity and lymphomagenesis. Mucosal Immunol. 2009, 2, 8-23. [CrossRef] [PubMed]

19. Nikulina, M.; Habich, C.; Flohe, S.B.; Scott, F.W.; Kolb, H. Wheat gluten causes dendritic cell maturation and chemokine secretion. J. Immunol. 2004, 173, 1925-1933. [CrossRef] [PubMed]

20. Skovbjerg, H.; Koch, C.; Anthonsen, D.; Sjostrom, H. Deamidation and cross-linking of gliadin peptides by transglutaminases and the relation to celiac disease. Biochim. Biophys. Acta 2004, 1690, 220-230. [CrossRef] [PubMed]

21. Castellanos-Rubio, A.; Santin, I.; Irastorza, I.; Castano, L.; Carlos Vitoria, J.; Ramon Bilbao, J. TH17 (and TH1) signatures of intestinal biopsies of CD patients in response to gliadin. Autoimmunity 2009, 42, 69-73. [CrossRef] [PubMed]

22. Palova-Jelinkova, L.; Danova, K.; Drasarova, H.; Dvorak, M.; Funda, D.P.; Fundova, P.; Kotrbova-Kozak, A.; Cerna, M.; Kamanova, J.; Martin, S.F.; et al. Pepsin digest of wheat gliadin fraction increases production of IL-1 $\beta$ via TLR4/MyD88/TRIF/MAPK/NF- $\kappa$ B signaling pathway and an NLRP3 inflammasome activation. PLoS ONE 2013, 8, e62426. [CrossRef] [PubMed]

23. Di Sabatino, A.; Ciccocioppo, R.; Cupelli, F.; Cinque, B.; Millimaggi, D.; Clarkson, M.M.; Paulli, M.; Cifone, M.G.; Corazza, G.R. Epithelium derived interleukin 15 regulates intraepithelial lymphocyte Th1 cytokine production, cytotoxicity, and survival in coeliac disease. Gut 2006, 55, 469-477. [CrossRef] [PubMed]

24. Harris, K.M.; Fasano, A.; Mann, D.L. Monocytes differentiated with IL-15 support Th17 and Th1 responses to wheat gliadin: Implications for celiac disease. Clin. Immunol. 2010, 135, 430-439. [CrossRef] [PubMed]

25. De Nitto, D.; Monteleone, I.; Franze, E.; Pallone, F.; Monteleone, G. Involvement of interleukin-15 and interleukin-21, two $\gamma$-chain-related cytokines, in celiac disease. World J. Gastroenterol. 2009, 15, 4609-4614. [CrossRef] [PubMed]

26. Lammers, K.M.; Lu, R.; Brownley, J.; Lu, B.; Gerard, C.; Thomas, K.; Rallabhandi, P.; Shea-Donohue, T.; Tamiz, A.; Alkan, S.; et al. Gliadin induces an increase in intestinal permeability and zonulin release by binding to the chemokine receptor CXCR3. Gastroenterology 2008, 135, 194-204. [CrossRef] [PubMed]

27. Lammers, K.M.; Khandelwal, S.; Chaudhry, F.; Kryszak, D.; Puppa, E.L.; Casolaro, V.; Fasano, A. Identification of a novel immunomodulatory gliadin peptide that causes interleukin-8 release in a chemokine receptor CXCR3-dependent manner only in patients with coeliac disease. Immunology 2011, 132, 432-440. [CrossRef] [PubMed] 
28. Drago, S.; El Asmar, R.; di Pierro, M.; Grazia Clemente, M.; Tripathi, A.; Sapone, A.; Thakar, M.; Iacono, G.; Carroccio, A.; D’Agate, C.; et al. Gliadin, zonulin and gut permeability: Effects on celiac and non-celiac intestinal mucosa and intestinal cell lines. Scand. J. Gastroenterol. 2006, 41, 408-419. [CrossRef] [PubMed]

29. Fasano, A. Zonulin and its regulation of intestinal barrier function: The biological door to inflammation, autoimmunity, and cancer. Physiol. Rev. 2011, 91, 151-175. [CrossRef] [PubMed]

30. Garrote, J.A.; Gomez-Gonzalez, E.; Bernardo, D.; Arranz, E.; Chirdo, F. Celiac disease pathogenesis: The proinflammatory cytokine network. J. Pediatr. Gastroenterol. Nutr. 2008, 47 (Suppl. 1), S27-S32. [CrossRef] [PubMed]

31. Thomas, K.E.; Sapone, A.; Fasano, A.; Vogel, S.N. Gliadin stimulation of murine macrophage inflammatory gene expression and intestinal permeability are MyD88-dependent: Role of the innate immune response in Celiac disease. J. Immunol. 2006, 176, 2512-2521. [CrossRef] [PubMed]

32. Ortega, C.; Fernandez, S.; Estevez, O.A.; Aguado, R.; Molina, I.J.; Santamaria, M. IL-17 producing $\mathrm{T}$ cells in celiac disease: Angels or devils? Int. Rev. Immunol. 2013, 32, 534-543. [CrossRef] [PubMed]

33. Anderson, R.P.; Degano, P.; Godkin, A.J.; Jewell, D.P.; Hill, A.V. In vivo antigen challenge in celiac disease identifies a single transglutaminase-modified peptide as the dominant A-gliadin T-cell epitope. Nat. Med. 2000, 6, 337-342. [CrossRef] [PubMed]

34. Shan, L.; Molberg, O.; Parrot, I.; Hausch, F.; Filiz, F.; Gray, G.M.; Sollid, L.M.; Khosla, C. Structural basis for gluten intolerance in celiac sprue. Science 2002, 297, 2275-2279. [CrossRef] [PubMed]

35. Camarca, M.E.; Mozzillo, E.; Nugnes, R.; Zito, E.; Falco, M.; Fattorusso, V.; Mobilia, S.; Buono, P.; Valerio, G.; Troncone, R.; et al. Celiac disease in type 1 diabetes mellitus. Ital. J. Pediatr. 2012, 38, 10. [CrossRef] [PubMed]

36. Rubio-Tapia, A.; Kyle, R.A.; Kaplan, E.L.; Johnson, D.R.; Page, W.; Erdtmann, F.; Brantner, T.L.; Kim, W.R.; Phelps, T.K.; Lahr, B.D.; et al. Increased prevalence and mortality in undiagnosed celiac disease. Gastroenterology 2009, 137, 88-93. [CrossRef] [PubMed]

37. Vilppula, A.; Kaukinen, K.; Luostarinen, L.; Krekela, I.; Patrikainen, H.; Valve, R.; Maki, M.; Collin, P. Increasing prevalence and high incidence of celiac disease in elderly people: A population-based study. BMC Gastroenterol. 2009, 9, 49. [CrossRef] [PubMed]

38. Kasarda, D.D. Can an increase in celiac disease be attributed to an increase in the gluten content of wheat as a consequence of wheat breeding? J. Agric. Food Chem. 2013, 61, 1155-1159. [CrossRef] [PubMed]

39. Hogberg, L.; Falth-Magnusson, K.; Grodzinsky, E.; Stenhammar, L. Familial prevalence of coeliac disease: A twenty-year follow-up study. Scand. J. Gastroenterol. 2003, 38, 61-65. [CrossRef] [PubMed]

40. Ivarsson, A.; Persson, L.A.; Nystrom, L.; Ascher, H.; Cavell, B.; Danielsson, L.; Dannaeus, A.; Lindberg, T.; Lindquist, B.; Stenhammar, L.; et al. Epidemic of coeliac disease in Swedish children. Acta Paediatr. 2000, 89, 165-171. [CrossRef] [PubMed] 
41. Ivarsson, A.; Myleus, A.; Norstrom, F.; van der Pals, M.; Rosen, A.; Hogberg, L.; Danielsson, L.; Halvarsson, B.; Hammarroth, S.; Hernell, O.; et al. Prevalence of childhood celiac disease and changes in infant feeding. Pediatrics 2013, 131, e687-e694. [CrossRef] [PubMed]

42. Liu, E.; Lee, H.S.; Aronsson, C.A.; Hagopian, W.A.; Koletzko, S.; Rewers, M.J.; Eisenbarth, G.S.; Bingley, P.J.; Bonifacio, E.; Simell, V.; et al. Risk of pediatric celiac disease according to HLA haplotype and country. N. Engl. J. Med. 2014, 371, 42-49. [CrossRef] [PubMed]

43. Hosea Blewett, H.J.; Cicalo, M.C.; Holland, C.D.; Field, C.J. The immunological components of human milk. Adv. Food Nutr. Res. 2008, 54, 45-80. [PubMed]

44. Newburg, D.S.; Walker, W.A. Protection of the neonate by the innate immune system of developing gut and of human milk. Pediatr. Res. 2007, 61, 2-8. [CrossRef] [PubMed]

45. Ivarsson, A.; Hernell, O.; Stenlund, H.; Persson, L.A. Breast-feeding protects against celiac disease. Am. J. Clin. Nutr. 2002, 75, 914-921. [PubMed]

46. Vriezinga, S.L.; Auricchio, R.; Bravi, E.; Castillejo, G.; Chmielewska, A.; Crespo Escobar, P.; Kolacek, S.; Koletzko, S.; Korponay-Szabo, I.R.; Mummert, E.; et al. Randomized feeding intervention in infants at high risk for celiac disease. N. Engl. J. Med. 2014, 371, 1304-1315.

47. Nadal, I.; Donat, E.; Ribes-Koninckx, C.; Calabuig, M.; Sanz, Y. Imbalance in the composition of the duodenal microbiota of children with coeliac disease. J. Med. Microbiol. 2007, 56, 1669-1674. [CrossRef] [PubMed]

48. Tjellstrom, B.; Hogberg, L.; Stenhammar, L.; Falth-Magnusson, K.; Magnusson, K.E.; Norin, E.; Sundqvist, T.; Midtvedt, T. Faecal short-chain fatty acid pattern in childhood coeliac disease is normalised after more than one year's gluten-free diet. Microb. Ecol. Health Dis. 2013, 24. [CrossRef] [PubMed]

49. Krumbhaar, E.B. Spontaneous Diabetes in a Dog. J. Exp. Med. 1916, 24, 361-365. [CrossRef]

50. Patterson, C.C.; Gyurus, E.; Rosenbauer, J.; Cinek, O.; Neu, A.; Schober, E.; Parslow, R.C.; Joner, G.; Svensson, J.; Castell, C.; et al. Trends in childhood type 1 diabetes incidence in Europe during 1989-2008: Evidence of non-uniformity over time in rates of increase. Diabetologia 2012, 55, 2142-2147. [CrossRef] [PubMed]

51. Patterson, C.C.; Dahlquist, G.G.; Gyurus, E.; Green, A.; Soltesz, G.; Group, E.S. Incidence trends for childhood type 1 diabetes in Europe during 1989-2003 and predicted new cases 2005-20: A multicentre prospective registration study. Lancet 2009, 373, 2027-2033. [CrossRef]

52. Harjutsalo, V.; Sjoberg, L.; Tuomilehto, J. Time trends in the incidence of type 1 diabetes in Finnish children: A cohort study. Lancet 2008, 371, 1777-1782. [CrossRef]

53. Tuomilehto, J. The emerging global epidemic of type 1 diabetes. Curr. Diab. Rep. 2013, 13, 795-804. [CrossRef] [PubMed]

54. Hagopian, W.A.; Lernmark, A.; Rewers, M.J.; Simell, O.G.; She, J.X.; Ziegler, A.G.; Krischer, J.P.; Akolkar, B. TEDDY_The Environmental Determinants of Diabetes in the Young: An observational clinical trial. Ann. N. Y. Acad. Sci. 2006, 1079, 320-326. [CrossRef] [PubMed]

55. Rewers, M.; Bugawan, T.L.; Norris, J.M.; Blair, A.; Beaty, B.; Hoffman, M.; McDuffie, R.S., Jr.; Hamman, R.F.; Klingensmith, G.; Eisenbarth, G.S.; et al. Newborn screening for HLA markers associated with IDDM: Diabetes autoimmunity study in the young (DAISY). Diabetologia 1996, 39, 807-812. [CrossRef] [PubMed] 
56. Skyler, J.S.; Greenbaum, C.J.; Lachin, J.M.; Leschek, E.; Rafkin-Mervis, L.; Savage, P.; Spain, L.; Type 1 Diabetes TrialNet Study Group. Type 1 Diabetes TrialNet-An international collaborative clinical trials network. Ann. N. Y. Acad. Sci. 2008, 1150, 14-24. [CrossRef] [PubMed]

57. Foster, B. Diabetic Coma: Acetonaemia. Br. Med. J. 1878, 1, 78-81. [CrossRef] [PubMed]

58. American Diabetes Association. Standards of medical care in diabetes-2012. Diabetes Care 2012, 35 (Suppl. 1), S11-S63.

59. Bottazzo, G.F.; Florin-Christensen, A.; Doniach, D. Islet-cell antibodies in diabetes mellitus with autoimmune polyendocrine deficiencies. Lancet 1974, 2, 1279-1283. [CrossRef]

60. Palmer, J.P.; Asplin, C.M.; Clemons, P.; Lyen, K.; Tatpati, O.; Raghu, P.K.; Paquette, T.L. Insulin antibodies in insulin-dependent diabetics before insulin treatment. Science 1983, 222, 1337-1339. [CrossRef] [PubMed]

61. Baekkeskov, S.; Aanstoot, H.J.; Christgau, S.; Reetz, A.; Solimena, M.; Cascalho, M.; Folli, F.; Richter-Olesen, H.; de Camilli, P. Identification of the $64 \mathrm{~K}$ autoantigen in insulin-dependent diabetes as the GABA-synthesizing enzyme glutamic acid decarboxylase. Nature 1990, 347, 151-156. [CrossRef] [PubMed]

62. Atkinson, M.A.; Eisenbarth, G.S.; Michels, A.W. Type 1 diabetes. Lancet 2014, 383, 69-82.

63. Stankov, K.; Benc, D.; Draskovic, D. Genetic and epigenetic factors in etiology of diabetes mellitus type 1. Pediatrics 2013, 132, 1112-1122. [CrossRef] [PubMed]

64. Svejgaard, A.; Ryder, L.P. HLA and insulin-dependent diabetes: An overview. Genet. Epidemiol. 1989, 6, 1-14. [CrossRef] [PubMed]

65. Vella, A.; Cooper, J.D.; Lowe, C.E.; Walker, N.; Nutland, S.; Widmer, B.; Jones, R.; Ring, S.M.; McArdle, W.; Pembrey, M.E.; et al. Localization of a type 1 diabetes locus in the IL2RA/CD25 region by use of tag single-nucleotide polymorphisms. Am. J. Hum. Genet. 2005, 76, 773-779. [CrossRef] [PubMed]

66. Nistico, L.; Buzzetti, R.; Pritchard, L.E.; van der Auwera, B.; Giovannini, C.; Bosi, E.; Larrad, M.T.; Rios, M.S.; Chow, C.C.; Cockram, C.S.; et al. The CTLA-4 gene region of chromosome 2q33 is linked to, and associated with, type 1 diabetes. Belgian Diabetes Registry. Hum. Mol. Genet. 1996, 5, 1075-1080. [CrossRef] [PubMed]

67. Bottini, N.; Musumeci, L.; Alonso, A.; Rahmouni, S.; Nika, K.; Rostamkhani, M.; MacMurray, J.; Meloni, G.F.; Lucarelli, P.; Pellecchia, M.; et al. A functional variant of lymphoid tyrosine phosphatase is associated with type I diabetes. Nat. Genet. 2004, 36, 337-338. [CrossRef]

68. Nishimura, M.; Obayashi, H.; Maruya, E.; Ohta, M.; Tegoshi, H.; Fukui, M.; Hasegawa, G.; Shigeta, H.; Kitagawa, Y.; Nakano, K.; et al. Association between type 1 diabetes age-at-onset and intercellular adhesion molecule-1 (ICAM-1) gene polymorphism. Hum. Immunol. 2000, 61, 507-510. [CrossRef]

69. Bell, G.I.; Horita, S.; Karam, J.H. A polymorphic locus near the human insulin gene is associated with insulin-dependent diabetes mellitus. Diabetes 1984, 33, 176-183. [CrossRef] [PubMed]

70. Sadeharju, K.; Hamalainen, A.M.; Knip, M.; Lonnrot, M.; Koskela, P.; Virtanen, S.M.; Ilonen, J.; Akerblom, H.K.; Hyoty, H.; Finnish, T.S.G. Enterovirus infections as a risk factor for type I diabetes: Virus analyses in a dietary intervention trial. Clin. Exp. Immunol. 2003, 132, 271-277. [CrossRef] [PubMed] 
71. Lonnrot, M.; Knip, M.; Roivainen, M.; Koskela, P.; Akerblom, H.K.; Hyoty, H. Onset of type 1 diabetes mellitus in infancy after enterovirus infections. Diabet. Med. 1998, 15, 431-434. [CrossRef]

72. Hyoty, H.; Hiltunen, M.; Knip, M.; Laakkonen, M.; Vahasalo, P.; Karjalainen, J.; Koskela, P.; Roivainen, M.; Leinikki, P.; Hovi, T.; et al. A prospective study of the role of coxsackie B and other enterovirus infections in the pathogenesis of IDDM. Diabetes 1995, 44, 652-657. [CrossRef] [PubMed]

73. Muir, P.; Singh, N.B.; Banatvala, J.E. Enterovirus-specific serum IgA antibody responses in patients with acute infections, chronic cardiac disease, and recently diagnosed insulin-dependent diabetes mellitus. J. Med. Virol. 1990, 32, 236-242. [CrossRef] [PubMed]

74. Honeyman, M.C.; Stone, N.L.; Harrison, L.C. T-cell epitopes in type 1 diabetes autoantigen tyrosine phosphatase IA-2: Potential for mimicry with rotavirus and other environmental agents. Mol. Med. 1998, 4, 231-239. [PubMed]

75. Honeyman, M.C.; Coulson, B.S.; Stone, N.L.; Gellert, S.A.; Goldwater, P.N.; Steele, C.E.; Couper, J.J.; Tait, B.D.; Colman, P.G.; Harrison, L.C. Association between rotavirus infection and pancreatic islet autoimmunity in children at risk of developing type 1 diabetes. Diabetes 2000, 49, 1319-1324. [CrossRef] [PubMed]

76. Okada, H.; Kuhn, C.; Feillet, H.; Bach, J.F. The "hygiene hypothesis" for autoimmune and allergic diseases: An update. Clin. Exp. Immunol. 2010, 160, 1-9. [CrossRef] [PubMed]

77. Hu, C.; Wong, F.S.; Wen, L. Type 1 diabetes and gut microbiota: Friend or foe? Pharmacol. Res. 2015, 98, 9-15. [CrossRef] [PubMed]

78. Wen, L.; Ley, R.E.; Volchkov, P.Y.; Stranges, P.B.; Avanesyan, L.; Stonebraker, A.C.; Hu, C.; Wong, F.S.; Szot, G.L.; Bluestone, J.A.; et al. Innate immunity and intestinal microbiota in the development of Type 1 diabetes. Nature 2008, 455, 1109-1113. [CrossRef] [PubMed]

79. De Goffau, M.C.; Fuentes, S.; van den Bogert, B.; Honkanen, H.; de vos, W.M.; Welling, G.W.; Hyoty, H.; Harmsen, H.J. Aberrant gut microbiota composition at the onset of type 1 diabetes in young children. Diabetologia 2014, 57, 1569-1577. [CrossRef] [PubMed]

80. De Goffau, M.C.; Luopajarvi, K.; Knip, M.; Ilonen, J.; Ruohtula, T.; Harkonen, T.; Orivuori, L.; Hakala, S.; Welling, G.W.; Harmsen, H.J.; et al. Fecal microbiota composition differs between children with $\beta$-cell autoimmunity and those without. Diabetes 2013, 62, 1238-1244. [CrossRef] [PubMed]

81. Simmons, K.M.; Michels, A.W. Type 1 diabetes: A predictable disease. World J. Diabetes 2015, 6, 380-390. [CrossRef] [PubMed]

82. Mojibian, M.; Chakir, H.; Lefebvre, D.E.; Crookshank, J.A.; Sonier, B.; Keely, E.; Scott, F.W. Diabetes-specific HLA-DR-restricted proinflammatory T-cell response to wheat polypeptides in tissue transglutaminase antibody-negative patients with type 1 diabetes. Diabetes 2009, 58, 1789-1796. [CrossRef] [PubMed]

83. Auricchio, R.; Paparo, F.; Maglio, M.; Franzese, A.; Lombardi, F.; Valerio, G.; Nardone, G.; Percopo, S.; Greco, L.; Troncone, R. In vitro-deranged intestinal immune response to gliadin in type 1 diabetes. Diabetes 2004, 53, 1680-1683. [CrossRef] [PubMed] 
84. Troncone, R.; Franzese, A.; Mazzarella, G.; Paparo, F.; Auricchio, R.; Coto, I.; Mayer, M.; Greco, L. Gluten sensitivity in a subset of children with insulin dependent diabetes mellitus. Am. J. Gastroenterol. 2003, 98, 590-595. [CrossRef] [PubMed]

85. Klemetti, P.; Savilahti, E.; Ilonen, J.; Akerblom, H.K.; Vaarala, O. T-cell reactivity to wheat gluten in patients with insulin-dependent diabetes mellitus. Scand. J. Immunol. 1998, 47, 48-53. [CrossRef] [PubMed]

86. Larsen, J.; Weile, C.; Antvorskov, J.C.; Engkilde, K.; Nielsen, S.M.; Josefsen, K.; Buschard, K. Effect of dietary gluten on dendritic cells and innate immune subsets in BALB/c and NOD mice. PLoS ONE 2015, 10, e0118618. [CrossRef] [PubMed]

87. Hansen, C.H.; Krych, L.; Buschard, K.; Metzdorff, S.B.; Nellemann, C.; Hansen, L.H.; Nielsen, D.S.; Frokiaer, H.; Skov, S.; Hansen, A.K. A maternal gluten-free diet reduces inflammation and diabetes incidence in the offspring of NOD mice. Diabetes 2014, 63, 2821-2832. [CrossRef] [PubMed]

88. Schmid, S.; Koczwara, K.; Schwinghammer, S.; Lampasona, V.; Ziegler, A.G.; Bonifacio, E. Delayed exposure to wheat and barley proteins reduces diabetes incidence in non-obese diabetic mice. Clin. Immunol. 2004, 111, 108-118. [CrossRef] [PubMed]

89. Lamb, M.M.; Myers, M.A.; Barriga, K.; Zimmet, P.Z.; Rewers, M.; Norris, J.M. Maternal diet during pregnancy and islet autoimmunity in offspring. Pediatr. Diabetes 2008, 9, 135-141. [CrossRef] [PubMed]

90. Chmiel, R.; Beyerlein, A.; Knopff, A.; Hummel, S.; Ziegler, A.G.; Winkler, C. Early infant feeding and risk of developing islet autoimmunity and type 1 diabetes. Acta Diabetol. 2014, 52, 621-624. [CrossRef] [PubMed]

91. Ziegler, A.G.; Schmid, S.; Huber, D.; Hummel, M.; Bonifacio, E. Early infant feeding and risk of developing type 1 diabetes-associated autoantibodies. JAMA 2003, 290, 1721-1728. [CrossRef] [PubMed]

92. Elenberg, Y.; Shaoul, R. The role of infant nutrition in the prevention of future disease. Front. Pediatr. 2014, 2, 73. [CrossRef] [PubMed]

93. Wahlberg, J.; Vaarala, O.; Ludvigsson, J.; ABIS-Study Group. Dietary risk factors for the emergence of type 1 diabetes-related autoantibodies in 21/2 year-old Swedish children. Br. J. Nutr. 2006, 95, 603-608. [CrossRef] [PubMed]

94. Hummel, S.; Pfluger, M.; Hummel, M.; Bonifacio, E.; Ziegler, A.G. Primary dietary intervention study to reduce the risk of islet autoimmunity in children at increased risk for type 1 diabetes: The BABYDIET study. Diabetes Care 2011, 34, 1301-1305. [CrossRef] [PubMed]

95. Lamb, M.M.; Simpson, M.D.; Seifert, J.; Scott, F.W.; Rewers, M.; Norris, J.M. The association between IgG4 antibodies to dietary factors, islet autoimmunity and type 1 diabetes: The Diabetes Autoimmunity Study in the Young. PLoS ONE 2013, 8, e57936. [CrossRef] [PubMed]

96. Marietta, E.V.; Gomez, A.M.; Yeoman, C.; Tilahun, A.Y.; Clark, C.R.; Luckey, D.H.; Murray, J.A.; White, B.A.; Kudva, Y.C.; Rajagopalan, G. Low incidence of spontaneous type 1 diabetes in non-obese diabetic mice raised on gluten-free diets is associated with changes in the intestinal microbiome. PLoS ONE 2013, 8, e78687. [CrossRef] [PubMed] 
97. Sildorf, S.M.; Fredheim, S.; Svensson, J.; Buschard, K. Remission without insulin therapy on gluten-free diet in a 6-year old boy with type 1 diabetes mellitus. BMJ Case Rep 2012, 2012. [CrossRef] [PubMed]

98. Patrick, C.; Wang, G.S.; Lefebvre, D.E.; Crookshank, J.A.; Sonier, B.; Eberhard, C.; Mojibian, M.; Kennedy, C.R.; Brooks, S.P.; Kalmokoff, M.L.; et al. Promotion of autoimmune diabetes by cereal diet in the presence or absence of microbes associated with gut immune activation, regulatory imbalance, and altered cathelicidin antimicrobial Peptide. Diabetes 2013, 62, 2036-2047. [CrossRef] [PubMed]

99. Watts, T.; Berti, I.; Sapone, A.; Gerarduzzi, T.; Not, T.; Zielke, R.; Fasano, A. Role of the intestinal tight junction modulator zonulin in the pathogenesis of type I diabetes in BB diabetic-prone rats. Proc. Natl. Acad. Sci. USA 2005, 102, 2916-2921. [CrossRef] [PubMed]

100. Mackinder, M.; Allison, G.; Svolos, V.; Buchanan, E.; Johnston, A.; Cardigan, T.; Laird, N.; Duncan, H.; Fraser, K.; Edwards, C.A.; et al. Nutritional status, growth and disease management in children with single and dual diagnosis of type 1 diabetes mellitus and coeliac disease. BMC Gastroenterol. 2014, 14, 99. [CrossRef] [PubMed]

101. Tsouka, A.; Mahmud, F.H.; Marcon, M.A. Celiac Disease Associated with Type 1 Diabetes and Celiac Disease Alone: Are these patients different? J. Pediatr. Gastroenterol. Nutr. 2015. [CrossRef] [PubMed]

102. Castellaneta, S.; Piccinno, E.; Oliva, M.; Cristofori, F.; Vendemiale, M.; Ortolani, F.; Papadia, F.; Catassi, C.; Cavallo, L.; Francavilla, R. High rate of spontaneous normalization of celiac serology in a cohort of 446 children with type 1 diabetes: A prospective study. Diabetes Care 2015, 38, 760-766. [CrossRef] [PubMed]

103. Rohrer, T.R.; Wolf, J.; Liptay, S.; Zimmer, K.P.; Frohlich-Reiterer, E.; Scheuing, N.; Marg, W.; Stern, M.; Kapellen, T.M.; Hauffa, B.P.; et al. Microvascular Complications in Childhood-Onset Type 1 Diabetes and Celiac Disease: A Multicenter Longitudinal Analysis of 56,514 Patients From the German-Austrian DPV Database. Diabetes Care 2015, 38, 801-807. [CrossRef] [PubMed]

104. Larizza, D.; Calcaterra, V.; Klersy, C.; Badulli, C.; Caramagna, C.; Ricci, A.; Brambilla, P.; Salvaneschi, L.; Martinetti, M. Common immunogenetic profile in children with multiple autoimmune diseases: The signature of HLA-DQ pleiotropic genes. Autoimmunity 2012, 45, 470-475. [CrossRef] [PubMed]

105. Bakker, S.F.; Tushuizen, M.E.; Stokvis-Brantsma, W.H.; Aanstoot, H.J.; Winterdijk, P.; van Setten, P.A.; von Blomberg, B.M.; Mulder, C.J.; Simsek, S. Frequent delay of coeliac disease diagnosis in symptomatic patients with type 1 diabetes mellitus: Clinical and genetic characteristics. Eur. J. Intern. Med. 2013, 24, 456-460. [CrossRef] [PubMed]

106. Bakker, S.F.; Tushuizen, M.E.; von Blomberg, M.E.; Mulder, C.J.; Simsek, S. Type 1 diabetes and celiac disease in adults: Glycemic control and diabetic complications. Acta Diabetol. 2013, 50, 319-324. [CrossRef] [PubMed]

107. Narula, P.; Porter, L.; Langton, J.; Rao, V.; Davies, P.; Cummins, C.; Kirk, J.; Barrett, T.; Protheroe, S. Gastrointestinal symptoms in children with type 1 diabetes screened for celiac disease. Pediatrics 2009, 124, e489-e495. [CrossRef] [PubMed] 
108. Warncke, K.; Liptay, S.; Frohlich-Reiterer, E.; Scheuing, N.; Schebek, M.; Wolf, J.; Rohrer, T.R.; Meissner, T.; Holl, R.W. Vascular risk factors in children, adolescents, and young adults with type 1 diabetes complicated by celiac disease: Results from the DPV initiative. Pediatr. Diabetes 2015. [CrossRef] [PubMed]

109. Adlercreutz, E.H.; Wingren, C.J.; Vincente, R.P.; Merlo, J.; Agardh, D. Perinatal risk factors increase the risk of being affected by both type 1 diabetes and coeliac disease. Acta Paediatr. 2015, 104, 178-184. [CrossRef] [PubMed]

110. Setty-Shah, N.; Maranda, L.; Nwosu, B.U. Increased risk for vitamin d deficiency in obese children with both celiac disease and type 1 diabetes. Gastroenterol. Res. Pract. 2014, 2014. [CrossRef] [PubMed]

111. Joshi, A.S.; Varthakavi, P.K.; Bhagwat, N.M.; Chadha, M.D.; Mittal, S.S. Coeliac autoimmunity in type I diabetes mellitus. Arab. J. Gastroenterol. 2014, 15, 53-57. [CrossRef] [PubMed]

(C) 2015 by the authors; licensee MDPI, Basel, Switzerland. This article is an open access article distributed under the terms and conditions of the Creative Commons Attribution license (http://creativecommons.org/licenses/by/4.0/). 